\title{
Surface modification of barium titanate powder particles
}

\author{
D. Völtzke ${ }^{\mathrm{a}}$, S. Gablenz ${ }^{\mathrm{a}}$, H.-P. Abicht ${ }^{\mathrm{a}}$, R. Schneider ${ }^{\mathrm{b}}$, E. Pippel ${ }^{\mathrm{c}}$, J. Woltersdorf $^{\mathrm{c}}$, $^{*}$ \\ ${ }^{a}$ Martin-Luther-Universität Halle-Wittenberg, Fachbereich Chemie, Kurt-Mothes-Str. 2, D-06120 Halle, Germany \\ ${ }^{\mathrm{b}}$ Humboldt-Universität Berlin, Lehrstuhl für Kristallographie, Invalidenstr. 110, D-10115 Berlin, Germany \\ ${ }^{\mathrm{c}}$ Max-Planck-Institut für Mikrostrukturphysik Halle, Weinberg 2, D-06120 Halle, Germany
}

Received 7 January 1999; accepted 16 March 1999

\begin{abstract}
The surfaces of n-doped barium titanate $\left(\mathrm{BaTiO}_{3}\right)$ powder particles were modified by milling in a $\mathrm{Ca}\left(\mathrm{NO}_{3}\right)_{2}$ solution both at room temperature and under hydrothermal conditions before they were analyzed by electron energy loss spectroscopy and transmission electron microscopy down to the nanometer range.

The room temperature treated powders showed $\mathrm{BaTiO}_{3}$ particles covered with a $\mathrm{CaO} / \mathrm{BaO}$ layer. Heating these particles caused a shell of $(\mathrm{Ca}, \mathrm{Ba}) \mathrm{TiO}_{3}$ solid solution. Under hydrothermal conditions rectangular $\mathrm{CaTiO}_{3}$ crystallites precipitated on the surface of the $\mathrm{BaTiO}_{3}$ grains, which during heating transformed into a series of $\left(\mathrm{Ba}_{1-x} \mathrm{Ca}_{x}\right) \mathrm{TiO}_{3}$ particles. These modifications of the shell structure change the sintering behavior and thus the microstructure as well as the electrical properties of the final ceramics. Especially the room temperature resistance and the voltage withstanding of the ceramic increased compared to that of conventionally prepared materials of identical composition. (C) 1999 Elsevier Science S.A. All rights reserved.
\end{abstract}

Keywords: $\mathrm{BaTiO}_{3}$ ceramics; Microstructure; Electron energy-loss spectroscopy; Surface modification

\section{Introduction}

The influence of distilled water as the milling liquid on the surface properties of barium titanate $\left(\mathrm{BaTiO}_{3}\right)$ powders was described in detail [1,2]. At room temperature $\mathrm{BaTiO}_{3}$ is thermodynamically unstable in water having a $\mathrm{pH}$ value lower than 12 [3-5]. Under the influence of water and by mechanical activation during ball-milling $\mathrm{Ba}^{2+}$ ions are dissolved superficially from the $\mathrm{BaTiO}_{3}$ particles according to Eq. (1).

$\mathrm{BaTiO}_{3}$ (s) $+\mathrm{H}_{2} \mathrm{O} \rightleftarrows \mathrm{Ba}^{2+}$ (aq.) $+\mathrm{TiO}_{2}$ (s) $+2 \mathrm{OH}^{-}$(aq.)

For these materials, an amorphous $\mathrm{TiO}_{x}$ layer $(x \approx 2)$ of $3-5 \mathrm{~nm}$ in thickness was detected on the periphery of the $\mathrm{BaTiO}_{3}$ grains [2]. This $\mathrm{TiO}_{x}$ region acts as a protecting layer against further attack. Furthermore, the $\mathrm{pH}$ value and the $\mathrm{Ba}^{2+}$ concentration in the solution, increasing with the dissolution progress (Eq. (1)), prevent the immediate and complete dissolution of the $\mathrm{BaTiO}_{3}$ grains. The dissolution

*Corresponding author. Tel.: +49-345-5582-922; fax: +49-345-5511223

E-mail address: wolt@mpi-halle.de (J. Woltersdorf) of the $\mathrm{BaTiO}_{3}$ grains takes place by the diffusion of $\mathrm{Ba}^{2+}$ ions through the amorphous $\mathrm{TiO}_{x}$ layer until there is an equilibrium between $\mathrm{BaTiO}_{3}$ (s), $\mathrm{Ba}^{2+}$ (aq.) and $\mathrm{TiO}_{2}$ (s) under strong alkaline conditions. Following the amorphous $\mathrm{TiO}_{x}$ layer inwards, a crystalline defect-perovskite layer with a $\mathrm{Ba} / \mathrm{Ti}$ molar ratio increasing from about 0 (outside) to 1 (inside) was found. This layer depleted in barium has a thickness of about $10 \mathrm{~nm}$.

Under hydrothermal leaching conditions $\left(T=180^{\circ} \mathrm{C}\right)$ the mechanism of dissolution of $\mathrm{BaTiO}_{3}$ changes in the following way [6]. Both lattice constituents $\left(\mathrm{BaO}, \mathrm{TiO}_{2}\right)$ dissolve superficially at the same rate. There were no $\mathrm{Ba} / \mathrm{Ti}$ gradients in the remaining $\mathrm{BaTiO}_{3}$ grains. Barium enters into the aqueous phase as $\mathrm{Ba}^{2+}$ ions, titanium dissolves as $\mathrm{Ti}(\mathrm{OH})_{4}$ (solubility $10^{-8} \mathrm{~mol} / \mathrm{dm}^{3}$ [4]). The dissolved Ti-species polycondensate and precipitate as crystalline $\mathrm{TiO}_{2}$ on the surface of the $\mathrm{BaTiO}_{3}$ grains under the conditions described above.

The stability fields of $\mathrm{BaTiO}_{3}$ and $\mathrm{CaTiO}_{3}$ were investigated by Lencka and Riman [6]. They found that $\mathrm{CaTiO}_{3}$ crystallizes under hydrothermal conditions $(T=160-$ $200^{\circ} \mathrm{C}$ ), and they measured a $\mathrm{Ca}^{2+}$ concentration of $10^{-4} \mathrm{~mol} / \mathrm{dm}^{3}$ at $\mathrm{pH}$ values higher than 8 . The stability region of $\mathrm{BaTiO}_{3}$ under comparable conditions is shifted to higher $\mathrm{pH}$ values by one unit. 
The aim of the investigations presented here was to change the destructive modification of the $\mathrm{BaTiO}_{3}$ surface caused by milling in water into a substituting one by milling in a $\mathrm{Ca}^{2+}$ containing medium. The basic idea is as follows. Starting with $\mathrm{BaTiO}_{3}$ particles in a neutral aqueous environment $\mathrm{BaTiO}_{3}$ dissolves superficially according to Eq. (1), and the $\mathrm{pH}$ value increases. If $\mathrm{Ca}^{2+}$ ions are present, $\mathrm{CaTiO}_{3}$ should form as the thermodynamically more stable phase as indicated by Eq. (2).

$$
\begin{gathered}
\mathrm{Ba}^{2+}+\mathrm{TiO}_{2} \text { (solid) }+2 \mathrm{OH}^{-}+\mathrm{Ca}^{2+}+2 \mathrm{NO}_{3}^{-} \\
\rightleftarrows \mathrm{CaTiO}_{3}(\text { solid })+\mathrm{Ba}^{2+}+2 \mathrm{NO}_{3}^{-}+\mathrm{H}_{2} \mathrm{O}
\end{gathered}
$$

In the literature, the influence of calcium substitutions in n-doped $\mathrm{BaTiO}_{3}$ ceramics is discussed in two different aspects: if $\mathrm{Ca}^{2+}$ ions are substituting $\mathrm{Ba}$-sites in the $\mathrm{BaTiO}_{3}$ structure the microstructure of the final ceramic is homogenized [7]. Under certain conditions the $\mathrm{Ca}^{2+}$-ions occupy Ti-sites forming acceptor defects $\mathrm{Ca}_{\mathrm{Ti}}^{\prime \prime}$, and thus increasing the voltage withstanding and the electrical resistance of the ceramic [8-10].

\section{Experimental}

There were two procedures to modify the surfaces of the $\mathrm{BaTiO}_{3}$ powder particles (and thus the grain boundaries of the processed ceramics) by $\mathrm{Ca}^{2+}$ ions:

1. The $\mathrm{BaTiO}_{3}$ starting powder of the composition $\mathrm{La}_{0.002} \mathrm{Ba}_{0.998} \mathrm{TiO}_{3}$ was prepared by the mixed oxide technique (calcination: $4 \mathrm{~h}$ at $1100^{\circ} \mathrm{C}$ ). The powder was ball milled for $24 \mathrm{~h}$ at room temperature using an aqueous $0.0235 \mathrm{M} \mathrm{Ca}\left(\mathrm{NO}_{3}\right)_{2}$ solution as the milling liquid.

2. The starting powder was crushed, and $20 \mathrm{~g}$ of this powder was stirred in $80 \mathrm{ml}$ of an aqueous $\mathrm{Ca}\left(\mathrm{NO}_{3}\right)_{2}$ solution $(0.044 \mathrm{M})$ in a laboratory autoclave (Berghof HR 200) under autogeneous pressure at $180^{\circ} \mathrm{C}$ for $24 \mathrm{~h}$.

After powder treatment both suspensions were separated. The liquid phase was analyzed by atomic absorption flame spectroscopy (Varian, Spectr AA 20 instrument). To simulate the reaction process in the surface layers during the sintering procedure of the ceramic bodies both powders were heated up to $1000^{\circ} \mathrm{C}$ and $1300^{\circ} \mathrm{C}$, respectively. The phase composition of the powders was studied by X-ray diffraction (Siemens D5000, $\mathrm{Cu} \mathrm{K}_{\alpha}$ radiation, monochromator, continuous scan mode, scan width $0.02^{\circ}, \mathrm{Si}$ as the inner standard). The interesting peculiarities concerning the microstructure and nanochemistry of the boundary layers or interfaces were investigated by high resolution and highvoltage electron microscopy (HREM, HVEM) and electron energy-loss spectroscopy (EELS), especially on near-edge fine structures (ELNES). EELS was performed with an energy resolution of $0.8-1 \mathrm{eV}$ using the Gatan imaging filter (GIF 200) attached to the transmission (TEM)/scan- ning transmission electron microscope (STEM) Philips CM 20 FEG operated at $200 \mathrm{keV}$. Either point analyses were made in the nanoprobe mode, or series of EEL spectra along a line were recorded in the STEM mode, with the electron probe of about 1-2 $\mathrm{nm}$ in diameter digitally scanned by the Gatan Digiscan model 688. For image and spectrum processing the software packages Digital Micrograph and EL/P of Gatan were used.

For TEM investigations, the specimens were prepared by dispersing a small amount of the powder in pure alcohol, mixing it in an ultrasonic generator, and pipetting a drop of this dispersion on a copper mesh covered with a holey Formvar film. To minimize contamination effects during the analyses, which are generally strong for small electron probes of some nanometers, the specimen grid was kept at liquid nitrogen temperature via a cooling specimen holder (Gatan model 668). To fabricate ceramic bodies the powders were mixed with $5 \mathrm{wt} \%$ poly(vinyl alcohol) solution as a pressing aid for $24 \mathrm{~h}$, then pressed into pellets $(12 \mathrm{~mm}$ in diameter, $2 \mathrm{~mm}$ thick) of $3.1 \mathrm{~g} / \mathrm{cm}^{3}$ in density, and sintered in air $\left(1350^{\circ} \mathrm{C}, 1400^{\circ} \mathrm{C}, 1 \mathrm{~h}\right.$ annealing time $)$. For testing the electrical resistance the sintered pellets were first polished and then connected to gallium-indium eutectic to provide an ohmic contact. The electrical resistance at room temperature was determined by measuring the current $I$ at a voltage of $U=0.1 \mathrm{~V}$. The voltage withstanding was ascertained as the voltage value for minimum $I$ in the $I / U$ plot. This voltage value was correlated to the thickness of the pellet.

For electron probe microanalysis (CAMEBAX, Cameca) the samples were coated with carbon.

\section{Results and discussion}

\subsection{Procedure 1}

After $24 \mathrm{~h}$ of milling at room temperature, the Ba content was $0.54 \mathrm{~mol} \%$ (compared to the amount of barium in the starting powder) in the milling liquid. On the other hand, the $\mathrm{Ca}$ content in the milling liquid decreased to $20 \mathrm{~mol} \%$ (referring to the initial amount of $\mathrm{Ca}$ ), i.e. $0.45 \mathrm{~mol} \% \mathrm{Ca}$ (referring to the amount of barium in the starting powder) was fixed in the $\mathrm{BaTiO}_{3}$ powder. That means $80 \%$ of the dissolved $\mathrm{Ba}$ ions were replaced by $\mathrm{Ca}$ ions. The $\mathrm{pH}$ value of the solution after milling was 11 .

The microstructure and composition of this powder as revealed by the electron microscope techniques are summarized in Fig. 1: the TEM bright-field image (cf. Fig. 1(a)) shows a $\mathrm{BaTiO}_{3}$ powder particle, whereas Fig. 1(b) presents a series of EEL spectra recorded in the energy range between about 300 and $800 \mathrm{eV}$ along the line drawn in Fig. 1(a). Ca is clearly detected by its $\mathrm{L}_{23}$ edge in an outer zone extending up to $20-30 \mathrm{~nm}$ from the surface into the particle. Surprisingly, there is a surface-near zone of less than $10 \mathrm{~nm}$ in extension containing no, or only a small 
(a)

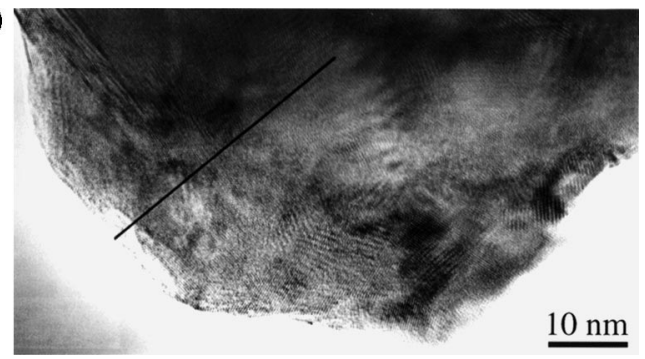

(b)

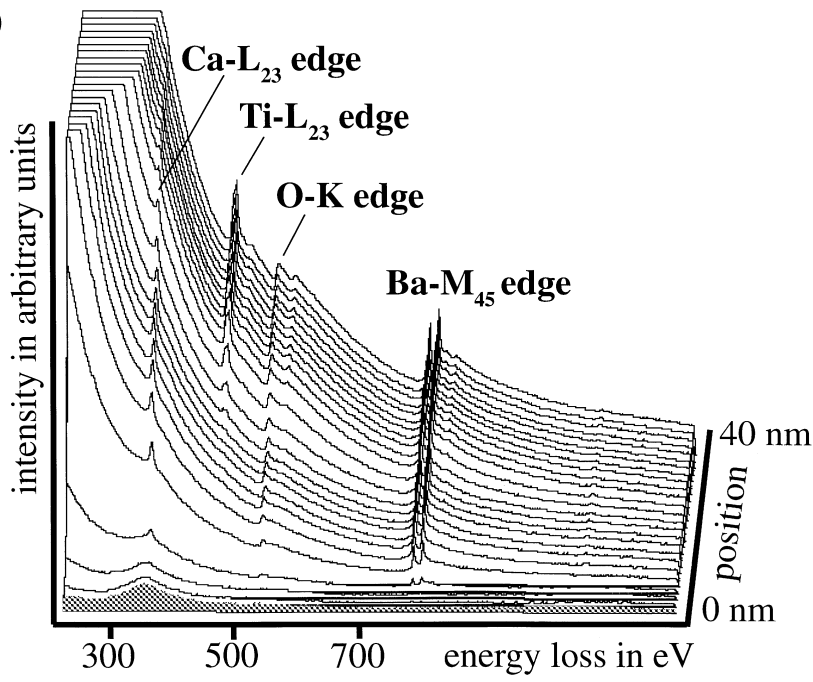

Fig. 1. EELS analysis of $\mathrm{BaTiO}_{3}$ particles after milling in $\mathrm{Ca}\left(\mathrm{NO}_{3}\right)_{2}$ solution at room temperature for $24 \mathrm{~h}$ : (a) TEM bright-field image of an individual particle, and (b) series of EEL spectra along the line marked in (a).

amount of, Ti. Since Ti is completely missing or partly depleted, the presence of a mixed $\mathrm{Ba} / \mathrm{Ca}$ oxide is assumed. Moreover, the O-K energy loss near edge structure (ELNES) measured in the outer part of the surface layer exhibits only a broad maximum without distinct fine structures which is typical of titanates. These results are interpreted by the help of the complex equation (3), using the Kröger-Vink-Notation [11]: (a)

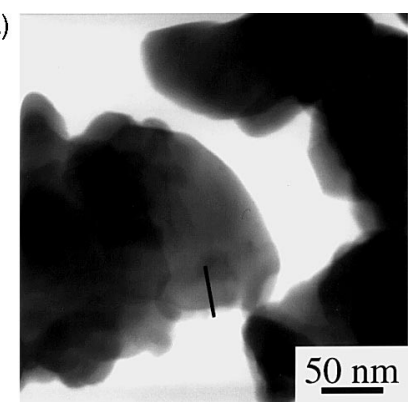

(b)

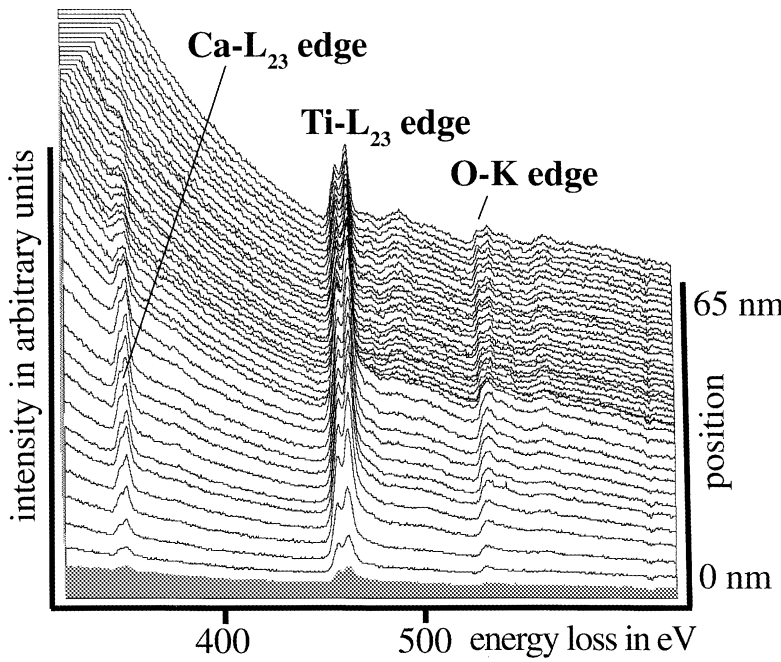

Fig. 2. EELS analysis of $\mathrm{BaTiO}_{3}$ particles after milling in $\mathrm{Ca}\left(\mathrm{NO}_{3}\right)_{2}$ solution at room temperature for $24 \mathrm{~h}$ and subsequent heating at $1000^{\circ} \mathrm{C}$ : (a) STEM bright-field image of single particles investigated, and (b) series of EEL spectra along the line marked in (a).

tion of the powder from the liquid and after annealing at $500^{\circ} \mathrm{C}, \mathrm{Ca}(\mathrm{OH})_{2}$, precipitated at the particle surface, is transformed into $\mathrm{CaO}$ and the $\mathrm{OH}_{\mathrm{O}}^{\circ}$ defects are removed according to

$$
2 \mathrm{OH}_{\mathrm{O}}^{\bullet} \rightleftarrows \mathrm{H}_{2} \mathrm{O}+\mathrm{O}_{\mathrm{O}}+\mathrm{V}_{\mathrm{O}}^{:}
$$

Heating the powder for $2 \mathrm{~h}$ at $1000^{\circ} \mathrm{C}$ changes the nanochemistry as follows. $\mathrm{Ba}$ and $\mathrm{Ca}$ ions diffuse into

$$
\begin{aligned}
& \left(\mathrm{Ba}_{\mathrm{Ba}}+\mathrm{Ti}_{\mathrm{Ti}}+3 \mathrm{O}_{\mathrm{O}}\right)_{\text {solid }}+x\left(\mathrm{Ca}^{2+}+2 \mathrm{NO}_{3}^{-}\right)_{\mathrm{liq}}+2 a \mathrm{H}_{2} \mathrm{O} \rightleftarrows\left[(1-a) \mathrm{Ba}_{\mathrm{Ba}}+a \mathrm{~V}_{\mathrm{Ba}}^{\prime \prime}+\mathrm{Ti}_{\mathrm{Ti}}+(3-2 a) \mathrm{O}_{\mathrm{O}}+2 a \mathrm{OH}_{\mathrm{O}}\right]_{\mathrm{solid}} \\
& +a \mathrm{Ba}^{2+}+2(a-b) \mathrm{OH}^{-}+(x-b) \mathrm{Ca}^{2+}+2 x \mathrm{NO}_{3}^{-}+b \mathrm{Ca}(\mathrm{OH})_{2} \quad(x>a>b ; a, b, x \ll 1)
\end{aligned}
$$

Milling in an aqueous $\mathrm{Ca}\left(\mathrm{NO}_{3}\right)_{2}$ solution causes the $\mathrm{Ba}$ ions to be dissolved from the $\mathrm{BaTiO}_{3}$ surface, as described in $[1,2]$. The resulting lattice defects $\mathrm{V}_{\mathrm{Ba}}^{\prime \prime}$ are electronically compensated by protons from the solution diffusing into the lattice, adhering to oxygen ions and thus forming positively charged $\mathrm{OH}_{\mathrm{O}}^{-}$defects. As a result the $\mathrm{pH}$ value of the solution increases, and $\mathrm{Ca}(\mathrm{OH})_{2}$ preferentially precipitates because the solubility product $K_{\mathrm{L}}$ of $\mathrm{Ca}(\mathrm{OH})_{2}$ is three orders of magnitude smaller than that of $\mathrm{Ba}(\mathrm{OH})_{2}$ $\left(\mathrm{p} K_{\mathrm{L}_{\mathrm{Ca}(\mathrm{OH})_{2}}}=4.78, \mathrm{p} K_{\mathrm{L}_{\mathrm{Ba}(\mathrm{OH})_{2}}}=1.5\right)$ [12]. After the separa- the inner region. The former depletion in Ti near the particle surface is not detectable as Fig. 2(b) shows. However, focusing on the $\mathrm{O}-\mathrm{K}$ edge reveals that in the direction to the core of the particle this zone is followed by another one exhibiting different ELNES features. A detailed analysis of particularly the Ti- $\mathrm{L}_{23}$ and $\mathrm{O}-\mathrm{K}$ edges was made to differentiate these regions (Fig. 3). For this purpose, the corresponding edges were taken from the series in Fig. 2(b) and presented in Fig. 3 with respect to their edge onset and shape. The O-K ELNES recorded at a depth of about $80 \mathrm{~nm}$ 


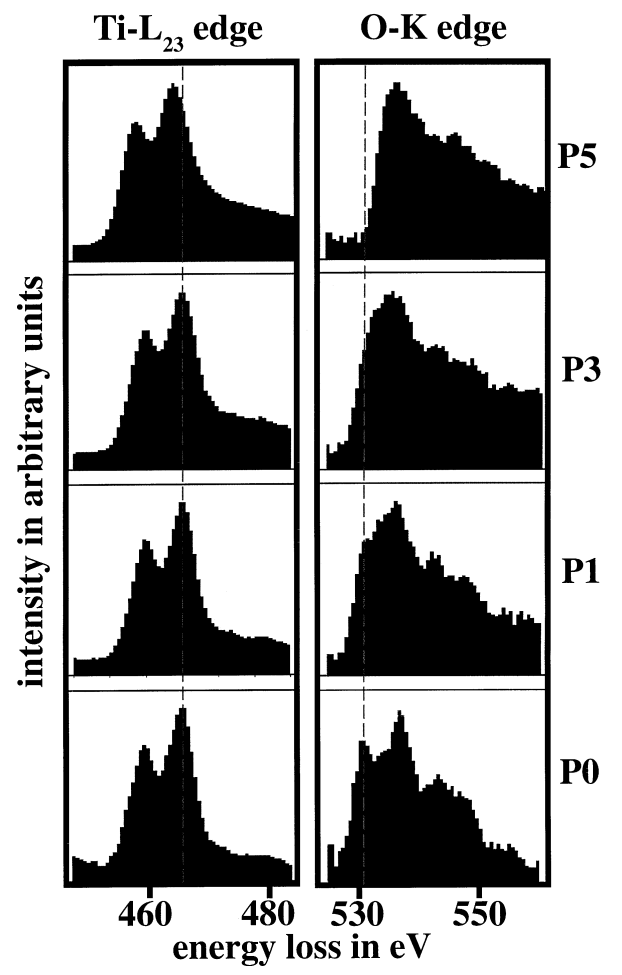

Fig. 3. ELNES details (onset and shape) of the Ti- $\mathrm{L}_{23}$ and $\mathrm{O}-\mathrm{K}$ edges depending on the lateral position of the electron probe taken from the series of EEL spectra shown in Fig. 2(b).

(measuring point $\mathrm{P}_{0}$ ) is in good agreement with that known of $\mathrm{BaTiO}_{3}$ [13]. Unlike that, the fine structure of the $\mathrm{O}-\mathrm{K}$ edge measured in the surface region $\left(\mathrm{P}_{5}\right)$ is quite different, particularly the first peak at about $531 \mathrm{eV}$ is missing. Moreover, the corresponding $\mathrm{Ti}-\mathrm{L}_{23}$ edge is shifted to lower energies by about $2 \mathrm{eV}$. Approaching the more central regions there is a gradual transition of the O-K ELNES to that of titanates (cf. $\mathrm{P}_{3}, \mathrm{P}_{1}$ ).

Hence, it is assumed that the surface-near zone represents a mixture of $\mathrm{Ba}-, \mathrm{Ca}-$, and Ti-oxides. Although the formation of orthotitanates $\left(\mathrm{Ba}_{2} \mathrm{TiO}_{4}\right.$ or $\left.\mathrm{BaCaTiO}_{4}\right)$ as well as Ruddlesden-Popper-phases [14] has been taken into account, there were no distinct hints of their existence. The adjoining inner region represents a mixed $\mathrm{Ba} / \mathrm{Ca}$ titanate showing an almost undisturbed perovskite structure.

\subsection{Procedure 2}

After hydrothermal modification of the $\mathrm{BaTiO}_{3}$ powder, the analysis of the mother liquid yielded a $\mathrm{Ba}$ content of $5.1 \mathrm{~mol} \%$ dissolved from the powder into the liquid, and a Ca content of $3.9 \mathrm{~mol} \%$ incorporated from the liquid into the solid (both referring to the amount of barium in the starting powder). After milling the $\mathrm{pH}$ value was about 10 . The $\mathrm{Ba}$ content dissolved using distilled water as leaching liquid under the same conditions was found to be $0.68 \mathrm{~mol} \%$. Consequently, there is a synergy factor of 7.5 (a)
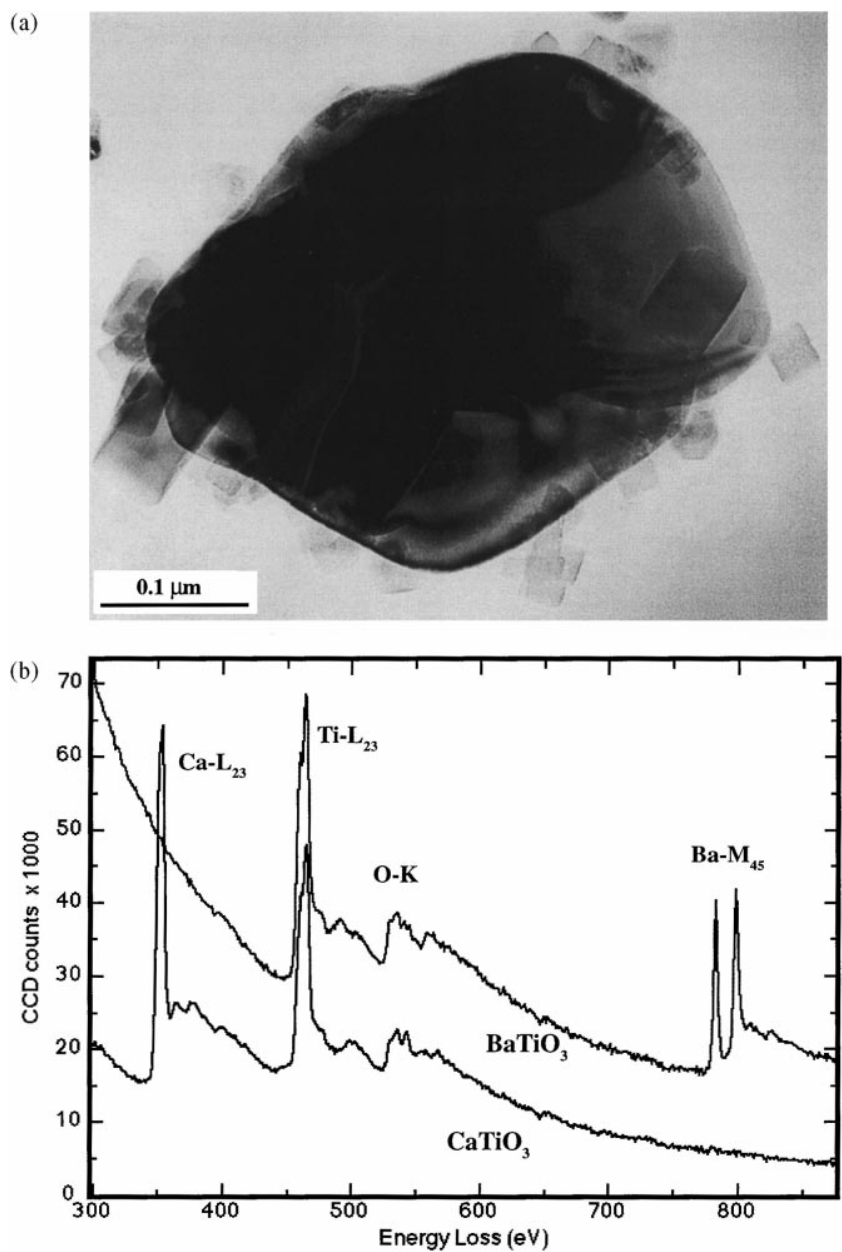

Fig. 4. Typical morphology of $\mathrm{BaTiO}_{3}$ powder hydrothermally treated in $\mathrm{Ca}\left(\mathrm{NO}_{3}\right)_{2}$ solution: (a) TEM bright-field image of a $\mathrm{BaTiO}_{3}$ grain surrounded by rectangular $\mathrm{CaTiO}_{3}$ crystallites, and (b) EEL spectra of the $\mathrm{BaTiO}_{3}$ grain (upper spectrum) and the $\mathrm{CaTiO}_{3}$ surrounding particles (lower spectrum).

(dissolved $\mathrm{Ba}$ content in a $\mathrm{Ca}\left(\mathrm{NO}_{3}\right)_{2}$ solution/dissolved $\mathrm{Ba}$ content in a $\mathrm{Ca}^{2+}$-free solution). This effect is contributed to additional equilibria appearing in the presence of $\mathrm{Ca}$ ions, e.g. the ion exchange in the perovskite structure.

The TEM micrograph of Fig. 4(a) clearly shows a coverage of the large grains with smaller rectangular crystallites. The EEL spectra of the respective particles, shown in Fig. 4(b), unambiguously identify the large particles as $\mathrm{BaTiO}_{3}$ (upper spectrum) and the smaller rectangular ones as $\mathrm{CaTiO}_{3}$ (lower spectrum). In particular, no radial element distribution gradients were detected in both kinds of crystallites. The phases were identified unambiguously (Fig. 4(b)) by the EELS fingerprint method. Heating the powders at $1300^{\circ} \mathrm{C}$ for $2 \mathrm{~h}$ completely changes the structure and composition of the particles covering the $\mathrm{BaTiO}_{3}$ crystals: as the TEM image of Fig. 5(a) shows, a large crystal is surrounded now by small irregularly shaped particles. The corresponding EEL spectra (cf. Fig. 5(b)) reveal that the large grain is again of $\mathrm{BaTiO}_{3}$ (upper spectrum), but the smaller adhering 
(a)

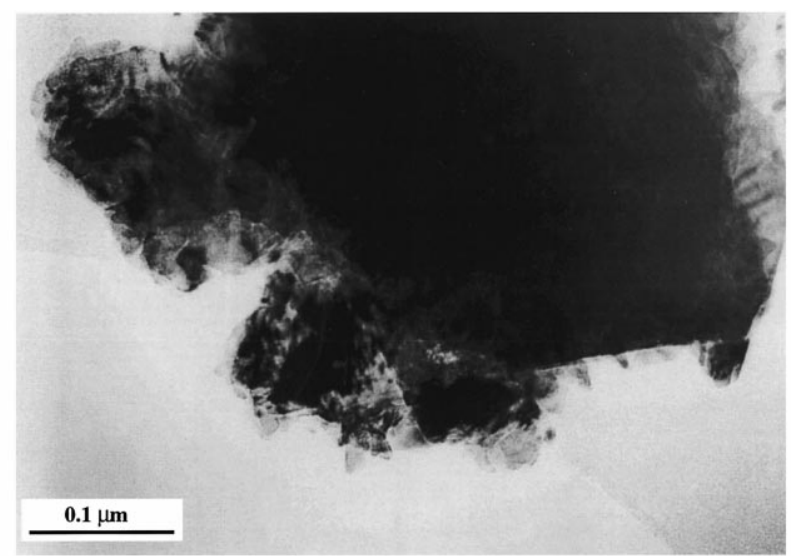

(b)

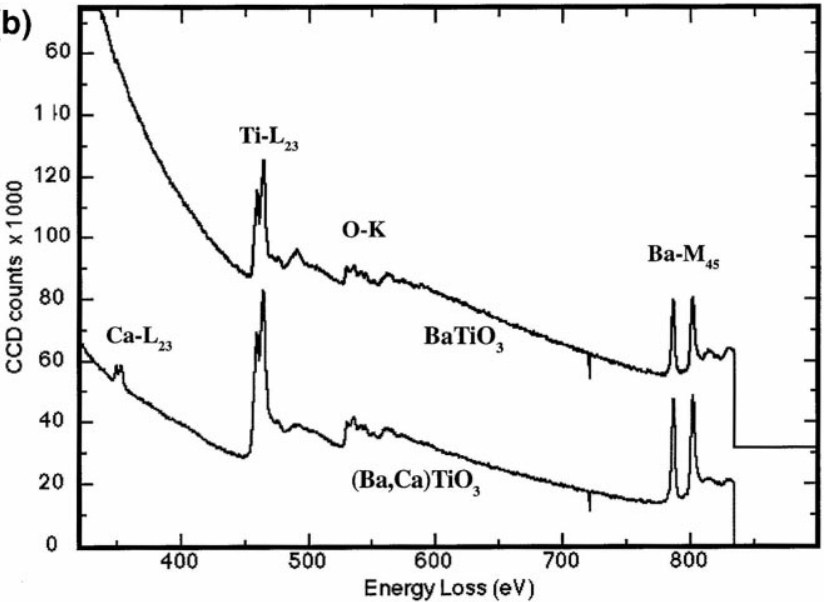

Fig. 5. Typical morphology of $\mathrm{BaTiO}_{3}$ powder hydrothermally treated in $\mathrm{Ca}\left(\mathrm{NO}_{3}\right)_{2}$ solution and subsequently heated at $1300^{\circ} \mathrm{C}$ : (a) TEM brightfield image of a $\mathrm{BaTiO}_{3}$ grain surrounded by irregularly shaped $\left(\mathrm{Ba}_{1-x} \mathrm{Ca}_{x}\right) \mathrm{TiO}_{3}$ crystallites, and (b) EEL spectra of the $\mathrm{BaTiO}_{3}$ grain (upper spectrum) and the $\left(\mathrm{Ba}_{1-x} \mathrm{Ca}_{x}\right) \mathrm{TiO}_{3}$ surrounding particles (lower spectrum).

particles are composed of barium titanate containing a small amount ( $5 \mathrm{vol} \%$ ) of $\mathrm{Ca}$ (lower spectrum). Probably, this is the result of a high-temperature diffusion between $\mathrm{BaTiO}_{3}$ and the adhering $\mathrm{CaTiO}_{3}$ crystals leading to the formation of $\left(\mathrm{Ba}_{1-x} \mathrm{Ca}_{x}\right) \mathrm{TiO}_{3}$. Surprising, however, is the observation that $\mathrm{Ca}$ is not so much uniformly distributed in the large $\mathrm{BaTiO}_{3}$ grains after heating, but rather aggregated in small $\left(\mathrm{Ba}_{1-x} \mathrm{Ca}_{x}\right) \mathrm{TiO}_{3}$ particles around them.

$\mathrm{X}$-ray diffraction studies confirmed these TEM/EELS findings, and moreover, they were also extented to other temperatures (Fig. 6(a)). After hydrothermal modification, besides $\mathrm{BaTiO}_{3}, \mathrm{CaTiO}_{3}$ and also $\mathrm{Ba}_{4} \mathrm{Ti}_{13} \mathrm{O}_{30}$ were identified as additional crystalline phases. These phases are stable up to $1000^{\circ} \mathrm{C}$. Below this temperature, no $(\mathrm{Ba}, \mathrm{Ca}) \mathrm{TiO}_{3}$ mixed-crystal formation was detected. At higher temperatures, solid state diffusion proceeds resulting in a series of different $\left(\mathrm{Ba}_{1-x} \mathrm{Ca}_{x}\right) \mathrm{TiO}_{3}$ solid solutions with $x \leq 0.25$ [15]. At $1200^{\circ} \mathrm{C}, \mathrm{CaTiO}_{3}$ has not yet been detected (Fig. 6(a)), however, the XRD graph (Fig. 6(b)) proves a change in the line profile of the $\left(\begin{array}{lll}0 & 0\end{array}\right)$ and $\left(\begin{array}{l}2 \\ 0\end{array}\right)$ peaks of $\mathrm{BaTiO}_{3}$. With (a)

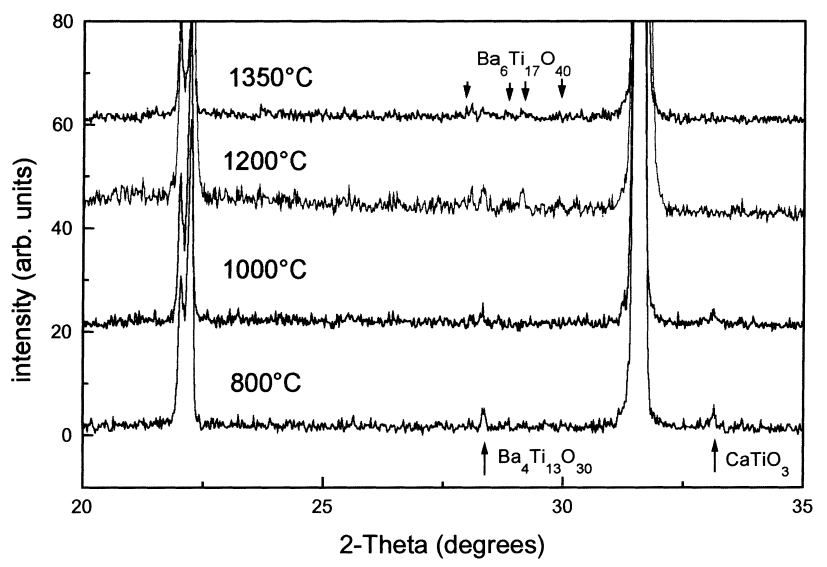

(b)

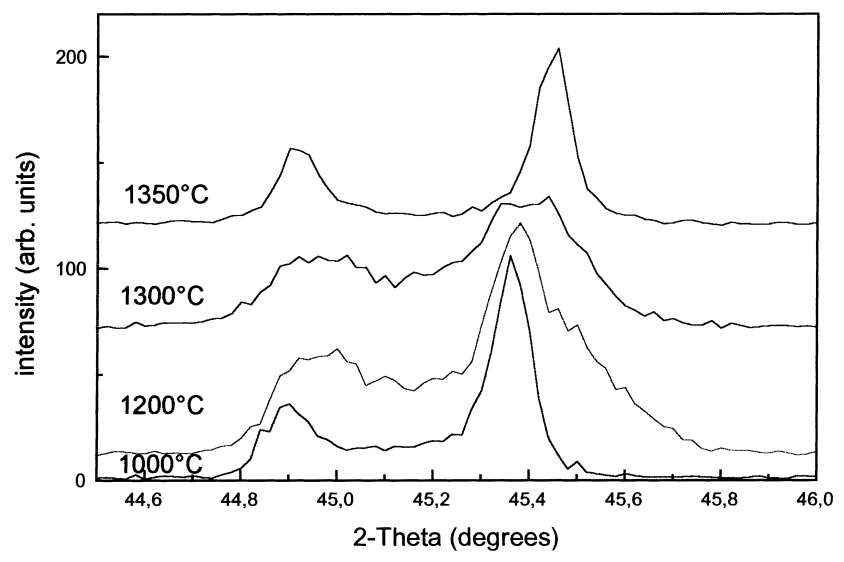

Fig. 6. XRD investigations of $\mathrm{BaTiO}_{3}$ powder hydrothermally treated in $\mathrm{Ca}\left(\mathrm{NO}_{3}\right)_{2}$ solution and annealed at different temperatures: (a) presenting minor phases, and (b) presenting the $\left(\begin{array}{lll}0 & 0 & 2\end{array}\right)$ and $\left(\begin{array}{lll}2 & 0 & 0\end{array}\right)$ peaks of $\mathrm{BaTiO}_{3}$.

increasing incorporation of the $\mathrm{Ca}$ ions into the $\mathrm{BaTiO}_{3}$ structure, the unit cell parameters decrease resulting in a shift of the peak position to higher $2 \Theta$ values. The XRD graph of the powder tempered at $1200^{\circ} \mathrm{C}$ clearly displays the changes in the high- $2 \Theta$ flank of the peaks. In the powder tempered at $1300^{\circ} \mathrm{C}$, these effects are still more pronounced and the intensity of the original, unmodified (2 00$)$ peak at $2 \Theta=45.36^{\circ}$ decreases considerably. At temperatures higher than $1320^{\circ} \mathrm{C}$, a eutectic forms in the $\mathrm{TiO}_{2}$ rich region of the $\mathrm{BaO}-\mathrm{TiO}_{2}$ system between $\mathrm{BaTiO}_{3}$ and $\mathrm{Ba}_{6} \mathrm{Ti}_{17} \mathrm{O}_{40}$. This eutectic mediates the recrystallization of the $\mathrm{BaTiO}_{3}$ matrix, thus homogenizing the element distribution and resulting in a sharpening of the peaks. The $(200)$ peak is located at $2 \Theta=45.46^{\circ}$ indicating a substitution of about $4 \mathrm{~mol} \% \mathrm{Ca}$ on the Ba sites.

\subsection{Electrical properties}

The effect of the hydrothermal Ca modification (Procedure 2) of the $\mathrm{BaTiO}_{3}$ powder (powder A) on the electrical 
Table 1

Specific resistance $\rho_{20}$ and voltage withstanding $E_{\max }$ of ceramics of comparable composition $\mathrm{La}_{0.002} \mathrm{Ba}_{0.958} \mathrm{Ca}_{0.04} \mathrm{TiO}_{3}$ prepared (A) by the hydrothermal modification of $\mathrm{La}_{0.002} \mathrm{Ba}_{0.998} \mathrm{TiO}_{3}$ in $\mathrm{Ca}\left(\mathrm{NO}_{3}\right)_{2}$-solution, (B) by the conventional mixed oxide method using $\mathrm{La}_{0.002} \mathrm{Ba}_{0.998} \mathrm{TiO}_{3}$ and $\left(\mathrm{CaCO}_{3}+\mathrm{TiO}_{2}\right)$ as starting materials, and $(\mathrm{C})$ by the conventional mixed oxide method using $\mathrm{BaCO}_{3}+\mathrm{CaCO}_{3}+\mathrm{TiO}_{2}+\mathrm{La}_{2}\left(\mathrm{C}_{2} \mathrm{O}_{4}\right)_{3} \cdot 9 \mathrm{H}_{2} \mathrm{O}$ as starting materials calcined for $2 \mathrm{~h}$ at $1100^{\circ} \mathrm{C}$

\begin{tabular}{lccc}
\hline Sintering temperature & A & B & C \\
\hline $1350^{\circ} \mathrm{C}$ & & & \\
$\rho_{20}(\Omega \mathrm{cm})$ & 174 & 68.5 & 19.3 \\
$E_{\max }(\mathrm{V} / \mathrm{mm})$ & 58.5 & 50.7 & 11.3 \\
$1400^{\circ} \mathrm{C}$ & & & \\
$\rho_{20}(\Omega \mathrm{cm})$ & & & 23.5 \\
$E_{\max }(\mathrm{V} / \mathrm{mm})$ & 46.8 & 68.4 & 12.7 \\
\hline
\end{tabular}

properties of the resulting ceramic was analyzed in comparison with ceramics prepared by conventional powders of comparable composition (powders $\mathrm{B}$ and $\mathrm{C}$ ), for details, see [1]. Powder $\mathrm{B}$ was prepared using $\mathrm{La}_{0.002} \mathrm{Ba}_{0.998} \mathrm{TiO}_{3}$ and $\left(\mathrm{CaCO}_{3}+\mathrm{TiO}_{2}\right)$, powder $\mathrm{C}$, by using $\mathrm{BaCO}_{3}+\mathrm{CaCO}_{3}+$ $\mathrm{TiO}_{2}+\mathrm{La}_{2}\left(\mathrm{C}_{2} \mathrm{O}_{4}\right)_{3} \cdot 9 \mathrm{H}_{2} \mathrm{O}$ as starting materials, both milled in water and calcined at $1100^{\circ} \mathrm{C}$ for $2 \mathrm{~h}$. The specific resistance at room temperature and the voltage withstanding of the corresponding ceramics sintered at $1350^{\circ} \mathrm{C}$ and $1400^{\circ} \mathrm{C}$ were measured. The results are summarized in Table 1 . It is clearly shown that

1. after the $\mathrm{BaTiO}_{3}$ powder has formed (powders A and B) the addition of $\mathrm{Ca}$-containing additives increases not only the voltage withstanding, but also the specific resistance of the ceramic compared to the material produced with powder $\mathrm{C}$;

2. the distribution of $\mathrm{CaTiO}_{3}$ crystallites on the surface of the $\mathrm{BaTiO}_{3}$ matrix powder produced by hydrothermal modification in $\mathrm{Ca}\left(\mathrm{NO}_{3}\right)_{2}$-solution (powder $\mathrm{A}$ ) further increases the voltage withstanding of the resulting ceramic compared to that produced by the conventionally prepared powder B.

The increase in the voltage withstanding is mainly attributed to the homogenization and the reduction of the grain size in the final ceramic. The mean diameter of the grains in the ceramic sintered at $1350^{\circ} \mathrm{C}$ was determined to be 8.3 , 11.1 and $45 \mu \mathrm{m}$ for ceramics A, B and C, respectively. The correlation of the voltage withstanding and the resistance of the ceramic to the number of grains per unit length showed similar values for ceramics A, B and C, i.e. the properties of the grain boundaries after recrystallization are the same for the three types of ceramics.

It is assumed that the reduction in the grain size of the ceramics derived from powder $\mathrm{A}$ is due to the change in nucleation as $\mathrm{CaTiO}_{3}$ crystallites act as seed grains. Electron probe microanalysis showed the existence of Ca-rich cores in grains of ceramics sintered at $1350^{\circ} \mathrm{C}$.

\section{Summary}

The surface of $n$-doped $\mathrm{BaTiO}_{3}$ powders was modified by being milled in a $\mathrm{Ca}\left(\mathrm{NO}_{3}\right)_{2}$ solution, first at room temperature, and second under hydrothermal conditions. The effects of these modifications were studied on a nanometer scale using TEM and EELS methods. In the first procedure, these investigations proved the existence of a thin $\mathrm{CaO} / \mathrm{BaO}$ shell on the $\mathrm{BaTiO}_{3}$ grains. By heating these powders a shell of $(\mathrm{Ba} / \mathrm{Ca}) \mathrm{TiO}_{3}$ is formed. In the second procedure, i.e. under hydrothermal conditions the leaching of the $\mathrm{BaTiO}_{3}$ powder in a $\mathrm{Ca}\left(\mathrm{NO}_{3}\right)_{2}$ solution leads to the crystallization of rectangular $\mathrm{CaTiO}_{3}$ crystallites on the surface of the $\mathrm{BaTiO}_{3}$ particles. At temperatures higher than $1000^{\circ} \mathrm{C}$ solid state diffusion produces a series of $\left(\mathrm{Ba}_{1-x} \mathrm{Ca}_{x}\right) \mathrm{TiO}_{3}$ solid solutions with the large $\mathrm{BaTiO}_{3}$ grains remaining $\mathrm{Ca}$-free, but the small original $\mathrm{CaTiO}_{3}$ particles transforming to $(\mathrm{Ba}, \mathrm{Ca})$ $\mathrm{TiO}_{3}$ mixed crystals.

These shell modifications of $\mathrm{BaTiO}_{3}$ powders influence the microstructure and the electrical properties of the final ceramic. The average grain size decreases, and consequently the voltage withstanding and the electrical resistance of the ceramics increase compared to that of conventionally prepared ceramics of identical composition. The reduction in grain size is attributed to changes in nucleation, with the original $\mathrm{CaTiO}_{3}$ particles acting as seeds. Electron probe microanalysis showed the existence of Ca-rich cores within the grain of a ceramic sintered at $1350^{\circ} \mathrm{C}$

\section{Acknowledgements}

The authors gratefully acknowledge the financial support by the Deutsche Forschungsgemeinschaft and by the fund of the chemical industry. The authors thank Dr. C. Eisenschmidt for his XRD investigations and Dr. H.T. Langhammer for his electrical measurements.

\section{References}

[1] H.-P. Abicht, D. Völtzke, A. Röder, R. Schneider, J. Woltersdorf, J. Mater. Chem. 7 (1997) 487.

[2] H.-P. Abicht, D. Völtzke, R. Schneider, J. Woltersdorf, O. Lichtenberger, Mater. Chem. Phys. 55 (1998) 188-192.

[3] M.M. Lencka, R.E. Riman, Chem. Mater. 5 (1993) 61.

[4] F. Moore, T. Ogasawara, Ceramica 42 (1996) 487.

[5] K. Osseo-Asare, F.J. Arriagada, J.H. Adair, Ceram. Trans. 1 (1988) 47-53.

[6] M.M. Lencka, R.E. Riman, Chem. Mater. 7 (1995) 18.

[7] P. Blanchart, D. Balestrieri, F. Weber, P. Abelard, Silic. Ind. 59 (1994) 47-52.

[8] H.Y. Han, J.B. Appleby, D.M. Smyth, J. Am. Ceram. Soc. 70 (1987) 96-100.

[9] T.F. Lin, C.T. Hu, I.N. Lin, J. Appl. Phys. 67 (1990) 1042-1047.

[10] D. Hennings, H. Schreinemacher, J. Eur. Ceram. Soc. 15 (1995) 795800 . 
[11] F.A. Kröger, H.J. Vink, in: F. Seitz, D. Turnbull (Eds.), Solid State Physics, vol. 3, Academic Press, New York, 1956, p. 307.

[12] G. Jander, E. Blasius, in: Lehrbuch der analytischen und präparativen anorganischen Chemie, Hirzel, Leipzig, 1969, p. 195.

[13] R. Schneider, F. Syrowatka, A. Röder, H.-P. Abicht, D. Völtzke, J.
Woltersdorf, Proceedings of the 11th European Congress on Electron Microscopy, Dublin, 26-30 August 1996, p. T11-34.

[14] K. Szot, C. Freiburg, M. Pawellzyk, Appl. Phys. A 53 (1991) 563567.

[15] R.C. De Vries, R. Roy, J. Am. Ceram. Soc. 38 (1955) 145. 